\title{
User Perspective Towards M-banking in Bangladesh: A Case Study Based on University Students
}

\author{
Syeeda Raisa Maliha \\ East West University, Dhaka, Bangladesh \\ E-mail: maliharaisa7799@gmail.com \\ Mustafa Nizamul Aziz \\ Senior Lecturer \\ East West University, Dhaka, Bangladesh \\ E-mail: mustafa.nizamul@gmail.com
}

Received: May OI, 2020

Accepted: June 05, 2020

Online Published: June 16, 2020

doi: I0.4628I/ijbmf.v4i2.62I

URL: https://doi.org/I0.4628I/ijbmf.v4i2.62I

\begin{abstract}
The focus of this study is on user perspective towards M-banking in Bangladesh and the case study is based on university students. The main purpose of this paper is the opinion of university students based on their preference of bank, time consumption, user-friendly service system, service quality, transaction service charge, the security of transactions and fraudulent activities. Both primary and secondary data have been used in this study. A survey has been conducted with 220 respondents, with a majority of male students where most of the respondents said that M-banking companies should provide more options. The majority of the respondents also believe that the company provides adequate security about the transaction process, although many students said that they have faced fraud activities with service. Bkash plays a major role in the market because the maximum number of students used Bkash, followed by Rocket, Nagad, etc. Their major concerns about the service revolve around the charges they have to pay and security issues. As the idea of M-banking is a completely new concept for Bangladesh, the opinions of university students can contribute significantly to helping them improve their service.
\end{abstract}

Keywords: M-Banking, Mobile Banking, University Students, bKash, Rocket, Nagad.

\section{Introduction}

Mobile financial service (MFS), also known as Mobile banking or M-banking in Bangladesh is a service provided by banks or other financial institutions where the service allows the customer to conduct financial transactions remotely using devices like a mobile phone. In recent days, the mobile banking industry has become very comprehensive in Bangladesh. Mobile banking provides wireless service to customers and enables them to conduct financial actions very easily in their daily life. The downside is that it takes an enormous effort to make the program accessible to the general public. They want to serve the country's lowincome group by providing convenient, safe, and reliable services to achieve a broader financial inclusion. Besides, they need to come up with different innovative ideas to be positioned on the market. It can be used easily for cash withdrawal and deposit. Mobile banking is creating a cashless society. These services are often made easier by the use of bank agents that allow mobile account holders to act as an independent agent even in locations outside bank branches. The mobile banking market has created new opportunities and applications in the financial market and customers have accepted this innovation very easily. That is why millions of consumers are using mobile banking all over the world.

\section{I.I Brief Overview of Current Mobile Banking Situation in Bangladesh}

Mobile banking has become the most attractive service in western countries. In recent years, M-banking is gaining popularity in Bangladesh as well. According to a report from the Daily Star, for the first time, Dutch-Bangla Bank Limited (DBBL) has introduced mobile banking services in this country and has started to spread the banking service from cities to remote areas. As of now, I5 banks have given their clients versatile money related administrations. 
Table I. Mobile Financial Services (MFS) comparative summary statement of January, 2020 and February, 2020

\begin{tabular}{|c|c|c|c|c|}
\hline $\begin{array}{c}\text { Serial } \\
\text { No. }\end{array}$ & Description & $\begin{array}{l}\text { Amount in January, } \\
2020\end{array}$ & $\begin{array}{l}\text { Amount in February, } \\
2020\end{array}$ & $\begin{array}{c}\text { \% Change (January, } \\
2020 \text { to February, 2020) }\end{array}$ \\
\hline $\mathrm{I}$ & $\begin{array}{l}\text { No. of Banks currently providing the } \\
\text { Services }\end{array}$ & 16.00 & 15.00 & $\begin{array}{c}\text { NCC Bank Ltd. has } \\
\text { closed all its MFS } \\
\text { accounts. }\end{array}$ \\
\hline 2 & No. of agents & $981,537.00$ & $985,914.00$ & $0.45 \%$ \\
\hline 3 & No. of registered clients in Lac & 809.16 & 818.57 & $1.16 \%$ \\
\hline 4 & No. of active accounts in Lac & 332.94 & 270.87 & $-18.64 \%$ \\
\hline 5 & No. of the total transaction & $230,090,192.00$ & $226,109,405.00$ & $-1.73 \%$ \\
\hline 6 & Total transaction in taka(in crore BDT) & $42,103.22$ & $41,334.79$ & $-1.83 \%$ \\
\hline 7 & No. of the daily average transaction & $7,422,264.26$ & $7,796,876.03$ & $5.05 \%$ \\
\hline 8 & $\begin{array}{l}\text { Average daily transaction (in crore } \\
\text { BDT) }\end{array}$ & $\mathrm{I}, 358 . \mathrm{I7}$ & $\mathrm{I}, 425.34$ & $4.95 \%$ \\
\hline 9 & Product-wise information & $\begin{array}{l}\text { Amount (in crore } \\
\text { BDT) }\end{array}$ & $\begin{array}{l}\text { Amount (in crore } \\
\text { BDT) }\end{array}$ & \\
\hline a. & Inward Remittance & 29.68 & 29.99 & $1.04 \%$ \\
\hline $\mathrm{b}$. & Cash In transaction & $\mathrm{I} 4,947.64$ & $\mathrm{I} 4,634.9 \mathrm{I}$ & $-2.09 \%$ \\
\hline c. & Cash-Out Transaction & $13,929.62$ & $\mathrm{I} 3,706 . \mathrm{I} 3$ & $-1.6 \%$ \\
\hline $\mathrm{d}$. & $\mathrm{P} 2 \mathrm{P}$ transaction & $10,077.95$ & $9,796.98$ & $-2.79 \%$ \\
\hline e. & Salary Disbursement (B2P) & $\mathrm{I}, 083.6 \mathrm{I}$ & $1,087.74$ & $0.38 \%$ \\
\hline f. & Utility Bill Payment (P2B) & 472.02 & $44 I .12$ & $-6.55 \%$ \\
\hline g. & Merchant Payment & 627.77 & 581.89 & $-7.31 \%$ \\
\hline h. & Government Payment & $\mathrm{I} 52.34$ & 275.50 & $80.84 \%$ \\
\hline i. & Others & 782.58 & 780.53 & $-0.26 \%$ \\
\hline
\end{tabular}

Source: Bangladesh Bank (2008)

\section{Literature Review}

Mobile banking has several different definitions, but if we look at all definitions, the meanings are quite similar. Sharma (20I I) stated that Mobile banking provides customers with wireless service and customers can easily conduct activities such as paying bills, cashing out, and so on. Bhuiyan and Rahman (2013) mentioned that the growth in mobile financial services depends not only on advancements in technology but also on consumer confidence in the services provided. Alam, Patwar, and Rahim (2013) mentioned several benefits of M-banking in one of his studies as well as the current scenario of MFS in Bangladesh. They have discovered many critical factors the create a negative impression in the minds of customers as well such as the risk of the transaction. They have revealed that the banks offering assistance using this channel guarantee that it lessens expenses and makes them increasingly efficient. Sharma and Singh (2009) found that people are concerned about M-banking especially regarding customer security issues like fraud or misuse of the account. Shahncaz, Amin, and Chowdhuri (2016) stated that mobile banking has become a very widely accepted financial service in Bangladesh as it offers affordable service to customers. The study identified mobile banking issues like security, cost, technology, and standardization of service as well. They identified the advantages and disadvantages of mobile banking as well as how to use it. The study evaluated mobile banking's user-friendliness. The biggest challenge here is the recent trend in criminal activities such as fraud, extortion, and social crime through MFS.

\section{Objectives of the Research}

- The primary objective of the study is to explain the current scenario and consumer satisfaction regarding M-Banking in Bangladesh. 
- The secondary objectives of the study are to identify the level of consumer satisfaction based on Bangladesh's mobile banking services, to emphasize on some recommendations for effective provision of M-banking services, and to discover the issues and prospects in mobile banking. This paper offers a scenario analysis of Bangladesh's mobile banking industry and an analysis of customer satisfaction and dissatisfaction. This kind of research will also open the door for further large-scale research to capture the industry and learn about the industry on a larger scale.

\section{Research Methodology}

The study is designed with a collection of both primary and secondary data. Most of the primary data were collected to establish the level of consumer satisfaction in mobile banking services. Except that, the majority of the documentation contained secondary data. As many organizations maintain high levels of data and information security, secondary information is limited to a certain degree. For the primary data, opinions from 220 respondents were collected via a questionnaire on Google Docs from university students. Additional information has been drawn out from different online sources, for example, the official site of all the mobile financial organizations, a few articles, and reports. The questions are directed towards the ease of the use of the service, market access, customer service, transaction policy, the possibility of fraud in the availability of products. The questions were structured in a way that participants could clearly understand them and express their opinion.

\section{Findings and Analysis}

The first part of the questionnaire consists of demographic information about the respondents and the second part consists of information regarding customer satisfaction.

The first question has been created to identify the gender of the respondents. Of the 220 respondents, I58 were male and 62 were female, with a percentage of $71.8 \%$ and $28.2 \%$ respectively.

The second question was shaped to identify the different age groups among the participants. Age is one of the most important demographic factors that influenced our survey Results. Here, we found out that $66.8 \%$ of the users of M-banking belong to the age group of 2I-23 years old, $20.5 \%$ belong to the age group of $24-27$ years old and I2.3\% of them belong to the age group of $18-20$ years and a very few of them are scattered in the group of 28-30 years old.

On the third question, we asked the students whether they have any mobile banking account or not. $89.1 \%$ of the total sample agreed that they have an account where $10.9 \%$ do not. This proves that the majority of university students nowadays have an account on mobile banking.

In the fourth question, we asked them what type of apps they use for mobile banking. We found out that Bkash is the market leader having an $88.2 \%$ vote from the respondents. Rocket holds the second position with a $25 \%$ vote followed by Nagad with $9.1 \%$, I-PAY with $0.9 \%$, U-CASH with $4.1 \%$, and others with $5.9 \%$ of the votes.

This question asks the amount of time mobile banking users have used the service. It is important to determine whether people are sticking to the service or are they just using it once or twice and getting rid of it. Sadly, from the survey, we found out that the majority of the users (41.8\%) have been using it for less than one year. This could mean two things. Either the users are not finding the service compatible, or they have only started using the service just a few months back, and whether they'll stick to it or not can be decided yet. The good news is $35.9 \%$ have used it for over a year, $15 \%$ have used it for more than three years and $7.3 \%$ have used it for more than five whole years.

Most people think this is a fantastic service with $48.2 \%$ of respondents saying that it's easy to use. Just $17.7 \%$ of people consider that using mobile banking services moderately easy. Only a few people consider it difficult (0.9\%) and very difficult $(0.5 \%)$ to use.

This query has the purpose of gaining insights about customer satisfaction regarding mobile banking services. $52.2 \%$ of the respondents feel that their current mobile banking service is quite fast where $18.2 \%$ believe that it's really fast. So, it can be established that most people are comfortable with the speed of their mobile banking service, but there is still space for improvement as $27.7 \%$ rated it average and almost $2 \%$ tagged it as a slow and very slow service.

The service fee represents the amount of money that you have to pay for the service. The vast numbers of Bangladeshis residents are shifting to electronic payments and banking. This question deals with the knowledge of the costs attached to the service. Here, the responses are pretty close to each other. $37.7 \%$ think that the charges are average, $30.9 \%$ think they are high and $30.5 \%$ think they are affordable.

One of the most significant highlights of mobile banking is that it enables you to manage your money via a mobile phone, which can be the reason behind a major security concern. Given the issue, it is necessary to recognize whether companies provide adequate safety or not. The survey results show that $52.3 \%$ say that the security of the transaction process is really good which is very good news for the rising industry and $12.3 \%$ think that it is excellent and $25.9 \%$ rated it as fair. This illustrates people's trust in companies. Only $6.8 \%$ believed the security to be poor and $2.7 \%$ find it very poor.

Most of our respondents stated that more mobile banking options should be offered with almost $92.3 \%$ of the respondents voting "yes" on the questionnaire. 
The question was to rate the service in terms of options like security, convenience, and speed. Incidentally, I8.6\% of the people marked their M-banking services as fast, $60.5 \%$ believed mobile banking to be convenient and $26.8 \%$ thought it was secure.

Most of our respondents ( $80 \%$ ) announce that customer service representatives provide them with the proper solution they ask for. Although $20 \%$ of respondents disagreed with the fact and that requires further work to make the customer service even better.

A large percentage (40.5\%) of the respondent's report having faced online banking fraud. Even though the majority of the people have not faced any fraud, 40.5 is a big percentage of people facing security issues and this is an issue that should concern mobile banking services.

A significant percentage $(62.7 \%)$ of our respondents are satisfied with the transaction limit, but the reason why the rest of the respondents are not satisfied requires further research.

The last question asked whether people are actually satisfied with M-banking services and fortunately, most of the people $(88.6 \%)$ answered favorably they are satisfied with the performance of the mobile banking services that they use.

\section{Recommendations}

- Customer Service: Companies need the depth of knowledge to operate in the customer care section so that they provide stronger support to customers as several users have faced difficulties while dealing with the service. They should improve their customer care services over the phone because some respondents have mentioned that often their lines are not reachable. In particular, the customer representatives have a greater responsibility to create a satisfying experience as they are the bridge between the company and the customers. Customer service is one of the support beams of the service company and the customer only seeks help and information from them. Most customers want instantaneous solutions. They should always keep their customer service open $24 / 7$ and make sure that the communication system is easy and understandable.

- Pin Issue: Pin issue is a consideration for several users. Often many users forget their pin, and face difficulties as their IDs get blocked. These were a big consideration for several users. Companies have to pay close attention to this segment. They need to verify through the voice call then fixed the verification so that they can ensure safety and at the same time, make it convenient for the users to regain their IDs if needed.

- Service Charge: Several study participants emphasized on the fact that there are huge service charges for continuous exchanges that might not always be affordable for the public at large. They should reduce the transaction cost for withdrawing money as the respondents have marked it as way too much. If they were to reduce the charge on money transactions, then mobile banking systems could get a boost.

- Expanded Facility: Companies need to collaborate with international companies like Pay-pal or Visa card so that customers have wider flexibility as well. They should provide a GIC account facility for the students who plan on going abroad.

- Security: Online banking customers face a massive dilemma with illegal activities. A circle of attackers has developed hacking techniques that can cause people financial damage. The corporation's first switch to a more improved security system had an additional advantage in acquiring a larger market share. They need to be more secured, need to do campaigns, or release more advertisements about their security policy and systems.

- Foreign Remittance: Bangladesh has quite an enormous amount of international remittance emerging from abroad, however not all financial services give them affordable and convenient facilities. Internet banking companies may design services that meet the needs of these segments to diversify their market share.

- Commission: The dealers and agents are significant company stakeholders. The commission rate is important for them to be satisfied; otherwise, they will shift to other choices.

- Awareness Promotion: Mobile companies need to focus on promoting awareness regarding mobile banking because many clients are losing their money due to fraudulent activities because of their lack of knowledge about the service.

\section{Conclusion}

Mobile banking has recently opened the path for cash related organizations to a brand-new territory with new opportunities for Bangladeshi people. Research shows that the individuals of Bangladesh have just acknowledged this advanced innovation without any difficulty, and if organizations can satisfy their latent capacity, versatile banking would be a tremendous achievement in the upcoming years. Be that as it may, money related organizations, for example, internet banking would quicken the nation's financial turn of events. Individuals in different nations are as of now gazing at the web banking circumstance and discussing the advantages of this activity. Through this way, organizations, for example, bKash have assumed a gigantic job by building up the portable financial industry. More prominent research should likewise be completed to satisfy individuals' guidelines and to isolate organizations. Portable banking additionally permits banks to help their client base, making versatile banking a 
framework which is mechanized and under traditional banking. However, as the transaction volume increases, it also raises more security concerns. In this extremely large market, Bangladesh Bank also plays a major role and must act as an adequate regulatory body to allow mobile banking to thrive. All the features of Mobile Banking make life so much easier. In mobile banking, PIN makes sure the perceived safety of money and prevents fraud transactions. Above the $52.3 \%$ respondent said that they are said satisfied with the transaction process and $88.6 \%$ respondent satisfied with mobile banking service. Most of the respondents said that mobile banking services are more friendly and easy. Almost 52.3\% of respondents said that mobile banking services are faster and have the quality of ratings. If mobile banking companies want to increase their customer share, they need to focus on their problems and need to fix them urgently. Also, they need to be concerned about cost, because many customers come from both rural and non-banked societies.

\section{References}

Alam, M. Z., Patwary, M. M., \& Rahim, M. A. (2013). Mobile money system: the Bangladesh experience. International Journal of Scientific and Research Publications, 3(I0), I-5.

Bhuiyan, M. S. R., \& Rahman, M. M. (2013). Implementation of mobile banking in Bangladesh: opportunities and challenges. IOSR Journal of Electronics Communication Engineering, I5(4), 53-58.

Bangladesh Bank. (2008). Mobile Financial Services. Retrieved from https://www.bb.org.bd/fnansys/paymentsys/mfsdata.php Shahncaz, M. A., Amin, M. B., \& Chowdhuri, A. S. M. M. B. (2016). Challenges of Mobile Banking in Bangladesh: A Study on Dhaka City. Independent Business Review, $9(\mathrm{I} / 2), 40-53$.

Sharma, A. (20II). Mobile banking as technology adoption and challenges. International Journal of Multidisciplinary Research, $I(6)$, I $47-I 57$.

Sharma, P., \& Singh, P. (2009). Users' perception of mobile banking-with special reference to Indore \& around. Review of Business \& Technology Research, 2(I), I-4.

\section{Copyrights}

Copyright for this article is retained by the author(s), with first publication rights granted to the journal. This is an open-access article distributed under the terms and conditions of the Creative Commons Attribution license (http://creativecommons.org/licenses/by/4.0/). 